\title{
Anti-glutamic Acid Decarboxylase Antibody-associated Cerebellar Ataxia: A Case Report
}

\author{
Anti-glutamik Asit Dekarboksilaz Antikoru İlişkili Serebellar Ataksi: Olgu Sunumu
}

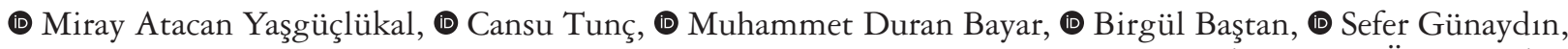
(1) Belgin Petek Balcı, (๑) Özlem Çokar

University of Health Sciences Turkey, Haseki Training and Research Hospital, Clinic of Neurology, Istanbul, Turkey

\begin{abstract}
Anti-glutamic acid decarboxylase antibodies (anti-GAD-ab) are associated with various neurologic conditions. High titers of anti-GAD-abs are observed in stiff person syndrome and subacute cerebellar degeneration. Type 1 diabetes mellitus (T1DM) and other autoimmune endocrinopathies may coexist in patients who are anti-GAD-ab positive. Herein, we describe a 62-year-old female patient with a past medical history of diabetes mellitus (DM) and smoking, presenting with gradual progression of gait ataxia, dizziness, and vertigo for 6 weeks. A neurologic examination revealed gaze-evoked nystagmus and left-sided dysmetria. She could stand up only with double-sided support. Laboratory examinations showed remarkably increased serum and cerebrospinal fluid anti-GAD-ab levels. Cerebral magnetic resonance imaging was unremarkable. Coexisting autoimmune endocrine diseases were also investigated and the patient was also diagnosed as having T1DM and Hashimoto thyroiditis. Paraneoplastic etiologies were excluded. Treatment was started with intravenous methylprednisolone. Due to a lack of significant clinical improvement, intravenous immunoglobulin (IVIG) was administered. With minimal improvement of gait ataxia, the patient was followed with prednisone $1 \mathrm{~g} /$ day for 1 day and then IVIG $400 \mathrm{mg} / \mathrm{kg} /$ day for 1 day once per month. Although it is a rare disease, anti-GAD-ab-associated cerebellar ataxia should be considered, especially in female patients with coexisting autoimmune disorders, for prompt initiation of immunotherapy.
\end{abstract}

Keywords: Autoimmunity, cerebellar ataxia, glutamic acid decarboxylase

$\ddot{\mathbf{O z}}$

Anti-glutamik asit dekarboksilaz antikorları (GAD-ab), çeşitli nörolojik durumlarla ilişkilidir. Stiff-person sendromu ve subakut serebellar dejenerasyonda yüksek GAD-ab titreleri gözlenmektedir. GAD-ab pozitif olan bu hastalarda tip 1 diabetes mellitus (T1DM) ve diğer otoimmün endokrinopatiler bir arada bulunabilir. Özgeçmişinde diabetes mellitus (DM) ve sigara kullanım öyküsü olan 62 yaşındaki hasta, 6 haftadır olan ve giderek ilerleyen yürüyüş ataksisi, sersemlik ve vertigo şikayetleri ile başvurdu. Nörolojik muayenesinde her yöne bakışta nistagmus, sol taraflı dismetri mevcuttu. Hasta çift taraflı destekle yürüyebiliyordu. Laboratuvar incelemelerinde serum ve BOS GAD-ab düzeyleri belirgin şekilde yüksekti. Serebral manyetik rezonans görüntülemesinde bir özellik saptanmadı. Eşlik eden otoimmün endokrin hastalıkların varlığı da araştırılan hastada T1DM ve Hashimoto tiroiditi saptandı. Paraneoplastik etiyolojiler dışlandı. Tedaviye intravenöz metilprednizolon başlandı. Yeterli klinik düzelme gözlenmemesi üzerine intravenöz immünoglobulin (IVIG) uygulandı. Yürüyüş ataksisinde hafif derecede iyileşme gözlenen hasta, ayda bir kez olmak üzere 1 gün boyunca $1 \mathrm{~g} /$ gün prednizon ve daha sonra 1 gün boyunca $400 \mathrm{mg} / \mathrm{kg} / \mathrm{gün}$ IVIG tedavisi ile izlendi. Nadir bir hastalık olmakla birlikte, eşlik eden otoimmün hastalıkları olan ileri yaş kadın hastalarda, immünoterapinin erken başlatılması için GAD-antikoruna bağlı serebellar ataksi tanısı akılda tutulmalıdır.

Anahtar Kelimeler: Glutamik asit dekarboksilaz, otoimmünite, serebellar ataksi

\section{Introduction}

Anti-glutamic acid decarboxylase antibodies (anti-GAD-ab) are associated with various neurologic conditions. Mostly found in type 1 diabetes mellitus (T1DM), high titers of anti-GAD-abs are associated with stiff person syndrome and subacute cerebellar degeneration. T1DM and other autoimmune endocrinopathies may coexist in patients who are anti-GAD-ab positive (1).

Address for Correspondence/Yazışma Adresi: Miray Atacan Yaşgüçlükal MD, University of Health Sciences Turkey, Haseki Training and Research Hospital, Clinic of Neurology, Istanbul, Turkey

Phone: +90 5347275634 E-mail: mirayatacan@hotmail.com ORCID: orcid.org/0000-0002-9529-1343 Received/Geliş Tarihi: 26.03.2020 Accepted/Kabul Tarihi: 05.10.2020

${ }^{\circ}$ Copyright 2021 by Turkish Neurological Society

Turkish Journal of Neurology published by Galenos Publishing House. 


\section{Case Report}

A 62-year-old female patient, with a past medical history of asthma, meningitis, 15 years of DM, hospitalization for diabetic ketoacidosis, and smoking, presented with a 6-week history of gait ataxia, dizziness, and vertigo. In the last two weeks, she was unable to walk without assistance. She also had difficulties in fine movements and coordination of the left hand.

A neurologic examination revealed gaze-evoked nystagmus and left-sided dysmetria. She could stand up only with doublesided support. Motor and sensory examinations were normal and deep tendon reflexes were normoactive. Neurologic disability was determined as 4 using the modified Rankin Scale (mRS). Cerebral magnetic resonance imaging (MRI) was unremarkable except for multiple white matter lesions and spinal MRI was normal.

Routine blood analysis, levels of vitamin B12, vitamin E, thyroid-stimulating hormone, ceruloplasmin, and 24-hour urine copper test were normal. The glycated hemoglobin level was $11.9 \%$. Anti-tissue transglutaminase, anti-gliadin immunoglobulin (Ig)-G, antinuclear antibody, extractable nuclear antigens, antineutrophil cytoplasmic antibody, antibodies to $\mathrm{HIV} 1 / 2$, hepatitis B virus, hepatitis C virus, Brucella, Borrelia burgdorferi, and Venereal Disease Research Laboratory test were negative. AntiGAD-ab was found positive $(2000 \mathrm{U} / \mathrm{ml})$ in serum using enzymelinked immunosorbent assay (Euroimmun, Luebeck, Germany). Cerebral spinal fluid (CSF) analysis showed 2 white blood cells/ $\mathrm{mm}^{3}, 5$ red blood cells $/ \mathrm{mm}^{3}$, normal protein level $(43 \mathrm{mg} / \mathrm{dl})$, a normal IgG index (0.59), and pattern 2 CSF oligoclonal bands. A panel for infectious disorders including polymerase chain reaction for viral meningitis pathogens and serologic studies for Brucella and syphilis proved negative in the CSF. Likewise, CSF culture for bacterial, fungal pathogens, and Mycobacterium tuberculosis was negative. Anti-GAD-ab was also found in the CSF (1020 IU/ml).

Thoraco-abdominal computed tomography, breast and gynecologic examinations, and a positron emission tomography scan performed to exclude a paraneoplastic etiology were all normal. Coexisting autoimmune endocrine diseases were also investigated. Low C-peptide levels and positive anti-islet antibodies were found. Anti-thyroid peroxidase antibodies were also positive culminating in the diagnosis of T1DM and Hashimoto thyroiditis.

Treatment was started with prednisone $1 \mathrm{~g} /$ day for 5 days. Due to a lack of significant clinical improvement, intravenous immunoglobulin (IVIG; $400 \mathrm{mg} / \mathrm{kg} /$ day) was administered for 5 days. Her gait ataxia was improved minimally. The patient was followed on prednisone $1 \mathrm{~g}$ /day for 1 day and then IVIG $400 \mathrm{mg} /$ $\mathrm{kg} /$ day for 1 day once per month with minimal improvement in a 2-month follow-up period. In the last neurologic examination, she could walk only with one-sided support (mRS: 4) and then she was lost to follow-up.

\section{Discussion}

GAD is essential in the formation of gamma aminobutyric acid (GABA), an inhibitory neurotransmitter found in the brain. AntiGAD-abs work against the GAD enzyme, thereby reducing levels of GABA, which results in motor and cognitive symptoms (2). The putative potential role of anti-GAD-ab in the cerebellum is a selective impairment of presynaptic GABA ergic transmission from cerebellar basket and stellate cells to Purkinje cells (3).
Anti-GAD-ab-associated cerebellar ataxia, a rare disorder with a prevalence of 1-2 cases per million (3) was described in 1995 by Honnorat et al. (4). Symptoms usually start in the fifth or sixth decades of life and women are overrepresented accounting for about $80-90 \%$ of cases $(1,5)$. Onset can be subacute, but cases of ataxia that slowly progresses over the course of years have been reported. The cerebellar syndrome is gait-predominant, but limb ataxia, nystagmus, and dysarthria are commonly seen (5). Limb ataxia is usually asymmetrical $(6,7,8)$. In a retrospective study, 20 of 34 patients with cerebellar ataxia and anti-GAD-ab showed asymmetrical limb ataxia (9). In addition, neuroimaging reports of asymmetrical cerebellar atrophy also exist $(6,7,10)$. The cause can be asymmetrical autoimmune-mediated impairment of GABA ergic transmission in the cerebellum.

Patients with anti-GAD-ab frequently have extra-neurologic autoimmune manifestations such as T1DM, polyendocrine autoimmune syndrome, pernicious anemia, and vitiligo. In a series of 17 patients with anti-GAD-ab-associated cerebellar ataxia, nine (53\%) patients had T1DM and seven (41\%) had thyroiditis (1). On the other hand, an underlying neoplasia has been reported in $12 \%$ of the patients. Small cell lung carcinoma, thymoma, and breast cancer are the most commonly associated tumors (3).

High anti-GAD-ab levels in serum, usually more than 100 -fold higher than those found in T1DM, are present in patients with anti-GAD-ab-associated cerebellar ataxia $(1,5)$. The diagnosis is based on the presence of high serum and CSF titers of anti-GAD$\mathrm{ab}$ and evidence for intrathecal production of antibodies (e.g. CSFspecific oligoclonal bands) (3). Induction therapies including the combination of intravenous methylprednisolone, IVIG, plasma exchange, and rituximab should be initiated at an early stage (11). There is no significant difference in the response to different types of immunotherapies. Maintenance therapies, such as oral steroids, repeated IVIG, immunosuppressants, and/or rituximab, alone or in combination, are also recommended (12). Subacute presentation, lack of cerebellar atrophy, and early initiation of treatment were suggested as good prognostic factors $(3,12)$.

In our case, a subacute presentation was observed in which symptoms evolved in around 6 weeks. The patient reported progressive gait ataxia followed by asymmetrical limb ataxia. A neurologic examination revealed typical cerebellar symptoms, gaze-evoked nystagmus, gait and limb ataxia. Additional laboratory tests revealed concomitant T1DM and Hashimoto thyroiditis. The detection of high serum and CSF titers of antiGAD-ab implicated the diagnosis of anti-GAD-ab-associated subacute cerebellar degeneration. Although no underlying tumors were found during the active presentation of neurologic symptoms, a paraneoplastic etiology cannot be entirely ruled out and thus the patient will need to be screened for an underlying tumor in the next 5 years. Despite the lack of cerebellar atrophy and early initiation of immunotherapy, the response to treatment was poor, indicating extensive loss of Purkinje cells in very early stages of the disease.

If there is suspicion of an autoimmune cerebellar ataxia, it is crucial to examine oligoclonal IgG bands and intrathecal synthesis of antibodies in CSF because high levels indicate immune-mediated damage of the cerebellum. Early onset of immunotherapy could reverse the cerebellar dysfunction in the absence of cerebellar atrophy (12). 
In conclusion, albeit a rare disease, anti-GAD-antibodyassociated cerebellar ataxia should be considered, especially in older female patients with coexisting autoimmune disorders, for prompt initiation of immunotherapy.

\section{Ethics}

Informed Consent: A consent form was signedby the patient. Peer-review: Externally peer-reviewed.

\section{Authorship Contributions}

Concept: B.B., S.G., Design: M.A.Y., B.B., Ö.Ç., Data Collection or Processing: M.A.Y., C.T., M.D.B., Ö.Ç., B.P.B., Analysis or Interpretation: B.B., Ö.Ç., B.P.B., S.G., Literature Search: M.A.Y., C.T., M.D.B., B.P.B., Writing: M.A.Y.

\section{References}

1. Saiz A, Blanco Y, Sabater L, et al. Spectrum of neurological syndromes associated with glutamic acid decarboxylase antibodies: Diagnostic clues for this association. Brain 2008;131:2553-2563.

2. Tohid H. Anti-glutamic acid decarboxylase antibody positive neurological syndromes. Neurosciences 2016;21:215-222.

3. Baizabal-Carvallo JF, Alonso-Juarez M. Cerebellar disease associated with anti-glutamic acid decarboxylase antibodies: review. J Neural Transm 2017; 124:1171-1182.

4. Honnorat J, Trouillas P, Thivolet C, Aguera M, Belin MF. Autoantibodies to glutamate decarboxylase in a patient with cerebellar cortical atrophy, peripheral neuropathy, and slow eye movements. Arch Neurol 1995;52:462468.

5. Honnorat J, Saiz A, Giometto B, et al. Cerebellar ataxia with antiglutamic acid decarboxylase antibodies: study of 14 patients. Arch Neurol 2001;58:225-230.

6. Kono S, Miyajima H, Sugimoto M, et al. Stiff-person syndrome associated with cerebellar ataxia and high glutamic acid decarboxylase antibody titer. Intern Med 2001;40:968-971.

7. Villa SM, Rufa A, Malandrini A, et al. Cerebellar ataxia associated with anti-glutamic acid decarboxylase antibodies: a case report. Neurol Sci 2019;40:1303-1306.

8. Kuchling J, Shababi-Klein J, Nümann A, et al. GAD antibody-associated late-onset cerebellar ataxia in two female siblings. Case Rep Neurol 2014;6:264-270.

9. Arino H, Gresa-Arribas N, Blanco Y, et al. Cerebellar ataxia and glutamic acid decarboxylase antibodies: immunologic profile and long-term effect of immunotherapy. JAMA Neurol 2014;71:1009-1016.

10. Hosoi Y, Suzuki-Sakao M, Terada T, et al. GABA-A receptor impairment in cerebellar ataxia with anti-glutamic acid decarboxylase antibodies. J Neurol 2013;260:3086-3092.

11. Mitoma H, Hadjivassiliou M, Honnorat J. Guidelines for treatment of immune-mediated cerebellar ataxias. Cerebellum Ataxias 2015;2:1-10.

12. Mitoma H, Manto M, Hampe CS. Immune-mediated cerebellar ataxias: practical guidelines and Therapeutic Challenges. Curr Neuropharmacol 2018;17:33-58. 